\title{
I HAVE PASSED TOO MANY YEARS AMONG COOL DESIGNING BEINGS
}

I have passed too many years among cool, designing beings.

I have contracted their reptile manner in my soul.

Last night I lay awake, judging the earth and all its creatures.

My dozen angry blood cells were frowning in the jury box.

Having nothing to say, I said nothing a long time. But now, Humiliated anger presses me cruelly...

I sketch a human hand: I leave the outline open-ended. Then I close off That open wrist-for I'm not here to draw but to quarter.

These worthless males! For them, the value of any sex act

Is measured by the market price of the photographic evidence.-

And these worthless females! Their religion is needlessly esoteric, And their Upper Realm is peopled by disreputable gods.

MADRID has written a paradox, calls it the paradox of the leash.

To solve it, you have to establish who's at the freer end of the strap. 